\title{
Interactive comment on "Temporal variation in carbon and nitrogen sequestration rates in boreal soils across a variety of ecosystems" by K. L. Manies et al.
}

\section{K. L. Manies et al. \\ kmanies@usgs.gov}

Received and published: 21 April 2016

Attached please find our manuscript revised according to reviewer comments.

Please also note the supplement to this comment:

http://www.biogeosciences-discuss.net/bg-2016-24/bg-2016-24-AC3-supplement.pdf 